\title{
Association of p53 codon 72 polymorphism with advanced lung cancer: the Arg allele is preferentially retained in tumours arising in Arg/Pro germline heterozygotes
}

\author{
ED Papadakis', N Soulitzis' and DA Spandidos*,' \\ 'Laboratory of Virology, Medical School, University of Crete, PO Box 1393, Heraklion, Crete, Greece
}

The association of p53 codon 72 polymorphism with cancer has been investigated by several scientific groups with controversial results. In the present study, we examined the genotypic frequency of this polymorphism in 54 patients with advanced lung cancer and 99 normal controls from the geographical region of Greece. Sputum and bronchial washing samples from each patient were assayed for the presence of human papillomavirus. Codon 72 heterozygous (Arg/Pro) patients were also analysed for loss of heterozygosity at the TP53 locus, in order to determine the lost p53 allele (Arg or Pro). p53 Arg/Arg genotype was significantly increased in lung cancer patients compared to normal controls $(50 \%$ vs $24.2 \%, P<0.002)$. Human papillomavirus was detected only in two patients (3.7\%). Loss of heterozygosity at the TP53 locus was found in 14 out of 27 Arg/Pro patients (51.85\%). The Pro allele was lost in II cases (78.6\%), while the Arg allele was lost in three (21.4\%). Our results suggest that p53 codon 72 Arg homozygosity is associated with advanced lung cancer, and that the Arg allele is preferentially retained in patients heterozygous for this polymorphism. On the other hand, human papillomavirus infection does not seem to play an important role in lung carcinogenesis.

British Journal of Cancer (2002) 87, I013-1018. doi:10.1038/sj.bjc.6600595 www.bjcancer.com

(c) 2002 Cancer Research UK

Keywords: p53; codon 72 polymorphism; lung cancer; human papillomavirus; loss of heterozygosity

Lung cancer is the most common cause of cancer-related deaths in Greece, accounting for 574 deaths per million people per year (Jemal et al, 2002). Radical treatment depends primarily on early detection, since patients with advanced and metastatic disease have 5 -year survival rates less than 5\% (Hirsch et al, 2001). Identification of early molecular events in lung carcinogenesis, such as ras gene mutations or $p 53$ inactivation, could have a major impact on early detection of this disease (Viallet and Minna, 1990).

Human papillomavirus (HPV) has been implicated in the development of several human cancers, including cervical, oesophageal, skin, and laryngeal cancer (zur Hausen, 1996). Among the proteins encoded in the HPV genome, early protein E6 binds p53 and promotes its degradation through the ubiquitin-dependent proteolytic pathway (Scheffner et al, 1990, 1993). HPV DNA is detected in less than $10 \%$ of lung cancer patients (Kinoshita et al, 1995; Bohlmeyer et al, 1998; Clavel et al, 2000), suggesting that HPV does not play an important role in the development of lung cancer.

The human p53 tumour suppressor gene is located on chromosome $17 \mathrm{p} 13$ and encodes a $53-\mathrm{kDa}$ nuclear phosphoprotein, which plays a central role in many cellular processes, such as DNA repair and apoptosis (Levine, 1997). Allelic loss at the TP53 locus is observed in more than $50 \%$ of human cancers, disclosing aberrations, like missense point mutations, in the retained allele (Hollstein et al, 1991). The p53 gene is mutated in more than $50 \%$ of lung cancer cases (Takahashi et al, 1991).

*Correspondence: Professor DA Spandidos;

E-mail: spandidos@spandidos.gr

Revised 14 August 2002; accepted 29 August 2002 p53 exists in two principal polymorphic forms that have either arginine ( $p 53 \mathrm{Arg})$ or proline (p53Pro) at codon 72 (Matlashewski et al, 1987). It has been proposed that p53Arg protein is more susceptible to inactivation through the E6-ubiquitin pathway than the p53Pro isoform, and that p53 Arg/Arg homozygosity is associated with increased risk of developing HPV-associated cervical cancer (Storey et al, 1998). Similar studies on cervical and other human cancers have produced contradictory results. Several groups confirmed the original finding (Makni et al, 2000; Zehbe et al, 2001), some have shown that the association between p53 Arg/Arg genotype and cancer is unrelated to HPV (Andersson et al, 2001), while others failed to find an association between p53Arg and cancer (Hamel et al, 2000; Tenti et al, 2000). In lung cancer, several studies found no correlation with p53 codon 72 polymorphism (Birgander et al, 1995; Pierce et al, 2000), while others have found an association with the Pro allele (Kawajiri et al, 1993; Wang et al, 1999; Fan et al, 2000). However, in tumours with loss of heterozygosity ( $\mathrm{LOH}$ ) at the TP53 locus, the Pro allele is preferentially deleted in germline Arg/Pro heterozygotes (Brooks et al, 2000; Kawaguchi et al, 2000; Furihata et al, 2002).

In this study we examined the genotypic frequency of $p 53$ codon 72 polymorphism and the presence of HPV infection in 54 patients with advanced lung cancer, compared to a healthy control population, in order to identify their association with lung carcinogenesis. Furthermore, using microsatellite analysis, we investigated the frequency of $\mathrm{LOH}$ at the TP53 locus, in patients heterozygous for the codon 72 polymorphism, in order to determine possible preferential retention of either Arg or Pro allele. 


\section{MATERIALS AND METHODS}

\section{Patients and controls}

Fifty-four Greek Caucasian patients with advanced lung cancer (Stages IIIb and IV) were recruited during the diagnostic workup for lung cancer in the Department of Pulmonary Medicine, University Clinic of Sotiria Hospital (Athens, Greece). Cancer staging was performed with CT scan and fiberoptic bronchoscopy. Mean age at diagnosis was $66.4 \pm 8.3$ years, with men accounting for $85.2 \%$ of cases. Patients were heavy smokers with an average of $64.6 \pm 31.4$ pack-years (Table 1). Histologically, cancer cases comprised 23 adenocarcinomas, 24 squamous cell carcinomas, six small cell lung carcinomas and one large cell carcinoma. Cytological specimens of sputum and bronchial washing were obtained from each patient and stored at $-80^{\circ} \mathrm{C}$ until DNA extraction. Matched peripheral blood samples were collected in tubes containing EDTA and stored at $4^{\circ} \mathrm{C}$, to serve as source of genomic DNA.

Ninety-nine Greek Caucasian healthy individuals served as the control group. They exhibited similar age, sex and smoking exposure distribution with patients (Table 1) and derived from the same geographical area. Peripheral blood samples were obtained from each individual and stored at $4{ }^{\circ} \mathrm{C}$ for further use.

The Ethics Committees of the University of Crete and the University Clinic of Sotiria Hospital approved this study and all participants gave written informed consent.

\section{DNA extraction}

Sputum, bronchial washing and peripheral blood samples from patients as well as peripheral blood samples from controls were lysed with $400 \mathrm{~mm}$ Tris- $\mathrm{HCl} \mathrm{pH} 8.0,150 \mathrm{~mm} \mathrm{NaCl}, 60 \mathrm{~mm}$ EDTA and $1 \%$ SDS, adding $50 \mu \mathrm{g}$ Proteinase $\mathrm{K}$ and incubated for $5 \mathrm{~h}$ at $65^{\circ} \mathrm{C}$.

DNA from all specimens was extracted with phenol/chloroform and chloroform, precipitated with absolute ethanol, washed with $70 \%$ ethanol and resuspended in $100 \mu \mathrm{l}$ double distilled water.

The presence of amplifiable DNA was tested in a PCR reaction using a set of primers for the $\beta 2$-microglobulin $(\beta 2-\mathrm{m})$ gene (Table 2).

\section{p53 codon 72 polymorphism analysis}

For the determination of the polymorphism at codon 72 of the $p 53$ gene, an allele-specific PCR assay was used (Storey et al, 1998), that selectively detects either the Arg or Pro p53 allele (Table 2). A total of $100 \mathrm{ng}$ of peripheral blood DNA from patients and controls was amplified in a PCR reaction containing $1 \times$ buffer $(20 \mathrm{~mm}$ Tris$\mathrm{HCl} \mathrm{pH} 8.4$ and $50 \mathrm{mM} \mathrm{KCl}), 1.6 \mathrm{mM} \mathrm{MgCl}_{2}, 200 \mu \mathrm{M}$ of each

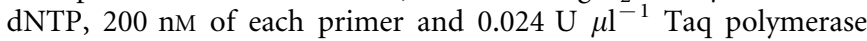
(Gibco BRL, Invitrogen Corporation) in a final volume of $25 \mu \mathrm{l}$. Detection of the two polymorphic variants was carried out in two different tubes. Amplification was performed as follows: initial denaturation at $94^{\circ} \mathrm{C}$ for $3 \mathrm{~min}$, amplification for 35 cycles at $94^{\circ} \mathrm{C}$ for $30 \mathrm{~s}, 60^{\circ} \mathrm{C}$ for the Arg allele and $54^{\circ} \mathrm{C}$ for the Pro allele for $30 \mathrm{~s}$ and $72^{\circ} \mathrm{C}$ for $30 \mathrm{~s}$, followed by a final elongation step at $72^{\circ} \mathrm{C}$ for $5 \mathrm{~min}$. PCR products were $141 \mathrm{bp}$ for the Arg allele and $177 \mathrm{bp}$ for the Pro allele. Heterozygous specimens had both PCR products, whereas homozygous samples exhibited only one of the two products. In each PCR reaction two blank samples were employed as negative controls, to ensure that no contaminants were introduced. PCR products were analysed by electrophoresis in a $2 \%$ agarose gel, stained with ethidium bromide and photographed on a UV light transilluminator. Procedures were repeated twice and results were $100 \%$ reproducible.

This analysis was also conducted in bronchial washing specimens from heterozygous (Arg/Pro) patients with $\mathrm{LOH}$ at the
Table I Descriptive characteristics of the study population

\begin{tabular}{lcc}
\hline & Lung cancer patients & Normal controls \\
\hline Cases, $n$ & 54 & 99 \\
Sex, $n(\%)$ & & \\
$\quad$ Male & $46(85.2 \%)$ & $84(84.8 \%)$ \\
$\quad$ Female & $8(14.8 \%)$ & $15(15.2 \%)$ \\
Age, mean \pm s.d., years & $66.4 \pm 8.3$ & $65.8 \pm 9.7$ \\
Pack-years, mean \pm s.d. & $64.6 \pm 31.4$ & $63.2 \pm 29.3$ \\
\hline
\end{tabular}

Table 2 Primer sequences and length of PCR products

\begin{tabular}{|c|c|c|}
\hline $\begin{array}{l}\text { Primer } \\
\text { pair }\end{array}$ & Sequence $5^{\prime}-3^{\prime}$ & $\begin{array}{l}\text { PCR product } \\
\text { size (bp) }\end{array}$ \\
\hline Arg & $\begin{array}{l}\text { TCC CCC TTG CCG TCC CAA } \\
\text { CTG GTG CAG GGG CCA CGC }\end{array}$ & $14 \mid$ \\
\hline Pro & $\begin{array}{l}\text { GCC AGA GGC TGC TCC CCC } \\
\text { CGT GCA AGT CAC AGA CTT }\end{array}$ & 177 \\
\hline TP53 & $\begin{array}{l}\text { ATC TAC AGT CCC CCT TGC CG } \\
\text { GCA ACT GAC CGT GCA AGT CA }\end{array}$ & 297 \\
\hline$\beta 2-m$ & $\begin{array}{l}\text { TCC AAC ATC AAC ATC TTG GT } \\
\text { TCC CCC AAA TTC TAA GCA GA }\end{array}$ & 123 \\
\hline $\begin{array}{l}\text { GP5 } \\
\text { GP6 }\end{array}$ & $\begin{array}{l}\text { TTT GTT ACT GTG GTA GAT AC } \\
\text { GAA AAA TAA ACT GTA AAT CA }\end{array}$ & $139-145$ \\
\hline HPV I8 & $\begin{array}{l}\text { AAA CTA ACT AAC ACT GGG TTA TAC A } \\
\text { ATG GCA CTG GCC TCT ATA GT }\end{array}$ & 143 \\
\hline HPV 16 & $\begin{array}{l}\text { CTG CAA GCA ACA GTT ACT GCG ACG } \\
\text { CAT ACA TCG ACC GGT CCA CC }\end{array}$ & 315 \\
\hline HPV II & $\begin{array}{l}\text { TGT GTG GCG AGA CAA CTT TCC CTT } \\
\text { TGG TTA TTT AGT TTT ATG AAG CGT GCC TTT CC }\end{array}$ & 236 \\
\hline HPV 33 & $\begin{array}{l}\text { AAC AGT TAA AAA ACC TTT AAA } \\
\text { AGT TTC TCT ACG TCG GGA CCT C }\end{array}$ & 171 \\
\hline
\end{tabular}

TP53 locus. Faint bands in the position of the lost allele were interpreted as DNA contamination from normal lung cells.

\section{LOH analysis at the TP53 locus}

For the determination of LOH at the TP53 locus, the TP53 microsatellite marker set was used (Table 2). A total of $100 \mathrm{ng}$ of peripheral blood and bronchial washing DNA from each heterozygous (Arg/Pro) patient was amplified in a PCR reaction containing $1 \times$ buffer, $2.66 \mathrm{mM} \mathrm{MgCl}_{2}, 500 \mu \mathrm{M}$ of each dNTP, $100 \mathrm{nM}$ of each primer and $0.04 \mathrm{U}^{-1}$ Taq polymerase in a final volume of $25 \mu$ l. Amplification was carried out as follows: initial heating at $94^{\circ} \mathrm{C}$ for $3 \mathrm{~min}$, amplification for 30 cycles at $94^{\circ} \mathrm{C}$ for $30 \mathrm{~s}$, $55^{\circ} \mathrm{C}$ for $30 \mathrm{~s}$ and $72^{\circ} \mathrm{C}$ for $30 \mathrm{~s}$ and final elongation at $72^{\circ} \mathrm{C}$ for $10 \mathrm{~min}$. PCR products were analysed by electrophoresis in a $10 \%$ polyacrylamide gel and silver stained. $\mathrm{LOH}$ was scored when a significant reduction $(>50 \%)$ in the intensity of one allele was observed. Most LOH cases exhibited faint bands in the position of deleted alleles, which was interpreted as contamination with normal DNA. Analysis in LOH positive cases was repeated at least twice and results were highly reproducible.

\section{HPV detection and typing}

For the detection of HPV genome, the general primers GP5 and GP6 were used (Table 2). A total of $100 \mathrm{ng}$ of sputum and bronchial washing DNA from each patient was amplified in a PCR reaction containing $1 \times$ buffer, $1.6 \mathrm{mM} \mathrm{MgCl}_{2}, 200 \mu \mathrm{M}$ of each 
dNTP, $200 \mathrm{nM}$ of each primer and $0.024 \mathrm{U}^{-1}$ Taq polymerase in a final volume of $25 \mu \mathrm{l}$. The mixture was heated at $94^{\circ} \mathrm{C}$ for $3 \mathrm{~min}$ and samples were amplified for 40 cycles at $94^{\circ} \mathrm{C}$ for $30 \mathrm{~s}, 52^{\circ} \mathrm{C}$ for $30 \mathrm{~s}$ and $72^{\circ} \mathrm{C}$ for $30 \mathrm{~s}$, followed by elongation at $72^{\circ} \mathrm{C}$ for $5 \mathrm{~min}$. PCR products were expected to be $139-145 \mathrm{bp}$, depending on HPV type (Snijders et al, 1990).

HPV typing of all HPV-positive samples was carried out using multiplex PCR. Specific pairs of primers were used to simultaneously amplify regions of HPV types $11,16,18$ and 33 in the same reaction tube, giving different lengths of amplified DNA. Each HPV-positive sputum or bronchial washing sample was amplified in a PCR reaction containing $1 \times$ buffer, $2.66 \mathrm{~mm}$ $\mathrm{MgCl}_{2}, 0.05 \% \mathrm{~W}-1,533 \mu \mathrm{M}$ of each dNTP, $166 \mathrm{nM}$ of each primer

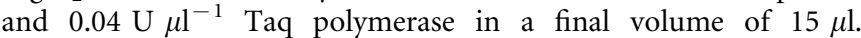
Amplification parameters were: initial heating at $94^{\circ} \mathrm{C}$ for $2 \mathrm{~min}$ and $30 \mathrm{~s}, 10$ cycles of amplification at $94^{\circ} \mathrm{C}$ for $30 \mathrm{~s}, 52^{\circ} \mathrm{C}$ for $40 \mathrm{~s}$ and $72^{\circ} \mathrm{C}$ for $45 \mathrm{~s}, 30$ cycles of amplification at $92^{\circ} \mathrm{C}$ for $30 \mathrm{~s}, 48^{\circ} \mathrm{C}$ for $40 \mathrm{~s}$ and $72^{\circ} \mathrm{C}$ for $45 \mathrm{~s}$, and final extension at $72^{\circ} \mathrm{C}$ for $10 \mathrm{~min}$. To establish type specificity of primer-directed amplification, each set of primers was tested with template plasmid DNA of the four HPV types $(11,16,18$ and 33$)$. PCR products were analysed by electrophoresis in a $2 \%$ agarose gel, stained with ethidium bromide and photographed on a UV light transilluminator. Primer sequences and length of PCR products are shown in Table 2.

\section{Statistical analysis}

Statistical analysis was performed using the $\chi^{2}$, Fisher's Exact and Mann - Whitney U tests, with the package SPSS 10.0 for Windows. Statistical significance was regarded at $P$-value $<0.05$.

\section{RESULTS}

\section{p53 Arg is associated with advanced lung cancer}

Peripheral blood DNA from 54 patients with advanced lung cancer was analysed, in order to determine the distribution of $p 53$ codon 72 polymorphism. In order to detect any discrepancy in the frequency of this polymorphism among cancer patients and the general population, peripheral blood specimens from 99 healthy individuals were subjected to the same PCR-based genotyping assay.

Distribution of the three genotypes, Arg/Arg, Arg/Pro and Pro/ Pro, was $50 \%, 50 \%$ and $0 \%$ in lung cancer patients, and $24.2 \%$, $64.7 \%$ and $11.1 \%$ in healthy controls respectively (Table 3 ). Based on the above results, the relative frequency of each allele was 0.75 for Arg and 0.25 for Pro in cancer patients, and 0.565 for Arg and 0.435 for Pro in normal controls, indicating a statistically significant difference $\left(\chi^{2}=7.99, P<0.005\right.$, odds ratio $(\mathrm{OR})=2.36,95 \%$ confidence intervals $(\mathrm{CI})=1.24-4.50)$. Further analysis revealed that the frequency of Arg/Arg genotype was considerably higher in patients than in controls $\left(\chi^{2}=10.43, P<0.002, \mathrm{OR}=3.13,95 \%\right.$

Table 3 Distribution of p53 codon 72 polymorphism among normal controls and various histological types of lung cancer

\begin{tabular}{lcccc}
\hline & Arg/Arg (\%) & Arg/Pro (\%) & Pro/Pro (\%) & Total \\
\hline Normal controls & $24(24.2)$ & $64(64.7)$ & $11(11.1)$ & 99 \\
Lung cancer type & & & & \\
$\quad$ Adenocarcinomas & $13(56.5)$ & $10(43.5)$ & $0(0)$ & 23 \\
Squamous cell carcinomas & $12(50.0)$ & $12(50.0)$ & $0(0)$ & 24 \\
Small cell carcinomas & $1(16.7)$ & $5(83.3)$ & $0(0)$ & 6 \\
Large cell carcinomas & $1(100)$ & $0(0)$ & $0(0)$ & 1 \\
Total & $27(50)$ & $27(50)$ & $0(0)$ & 54 \\
\hline
\end{tabular}

$\mathrm{CI}=1.46-6.73)$. This association was also observed separately in adenocarcinomas $\left(\chi^{2}=9.20, P<0.003, \mathrm{OR}=4.06,95 \% \mathrm{CI}=1.44-\right.$ $11.62)$ and squamous cell carcinomas $\left(\chi^{2}=6.19, \quad P<0.02\right.$, $\mathrm{OR}=3.13,95 \% \mathrm{CI}=1.13-8.69)$, but not in small cell lung carcinomas (Fisher's Exact test, $P=0.56$ ) or in large cell carcinomas (Fisher's Exact test, $P=0.25$ ).

Interestingly, both study groups (patients and controls) showed a deviation from the Hardy-Weinberg equilibrium due to excess of heterozygotes (Controls: $\chi_{\mathrm{HW}}^{2}=9.86, \mathrm{f}=1, P<0.002$; Patients: $\left.\chi_{\mathrm{HW}}^{2}=6.00, \mathrm{f}=1, P<0.02\right)$.

Patients were then stratified according to age, sex, histological classification and smoking exposure (in pack-years). A significant association of Arg/Arg adenocarcinomas with lower number of pack-years was observed, compared to Arg/Pro adenocarcinomas $(30 \pm 8.5$ vs $65 \pm 8.5) \quad$ (Mann-Whitney $\mathrm{U}$ test, $\mathrm{Z}=-4.073$, $P<0.001)$. No other statistically significant difference was found between the codon 72 polymorphism and the other variables examined.

\section{p53 Pro is preferentially deleted in Arg/Pro germline heterozygotes}

Lung cancer patients heterozygous for the codon 72 polymorphism (27 in total) were examined for LOH at the TP53 locus. Matched DNA samples from peripheral blood and bronchial washing were analysed, using the TP53 microsatellite marker (Figure 1B). A total of 14 of 27 Arg/Pro patients (51.85\%) exhibited LOH (Figure 1A). In order to identify the deleted $p 53$ allele, the 14 bronchial washing samples with $\mathrm{LOH}$ were analysed for the codon 72 polymorphism (Figure 1C, D). The Arg allele was preferentially retained, as it was lost only in three $(21.4 \%)$ cases, whereas the Pro allele was lost in $11(78.6 \%)$ cases (Table 4$)$

A

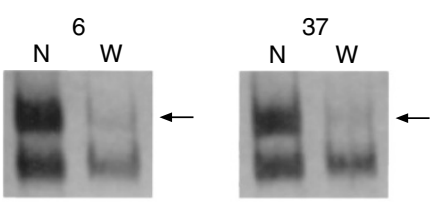

B

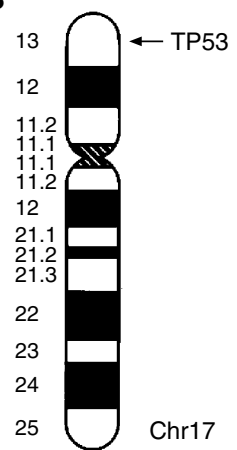

C

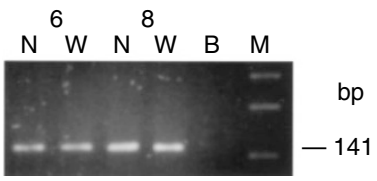

D

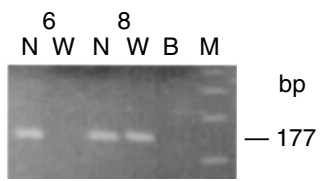

Figure I (A) Representative examples of specimens exhibiting $\mathrm{LOH}$ at the TP53 locus. N; DNA from peripheral blood lymphocytes. W; DNA extracted from bronchial washing. Arrows indicate the missing allele. The upper row indicates patient code number. (B) Location of the TP53 microsatellite marker at chromosome 17p 13. (C) PCR amplification of p53 codon $72 \mathrm{Arg}$ allele ( $14 \mid \mathrm{bp})$. N; DNA from peripheral blood lymphocytes. W; DNA extracted from bronchial washing. B; blank sample. M; 123 bp molecular weight marker. The upper row indicates patient code number. (D) PCR amplification of p53 codon 72 Pro allele ( $77 \mathrm{bp}$ ). N; DNA from peripheral blood lymphocytes. W; DNA extracted from bronchial washing. B; blank sample. M; 123 bp molecular weight marker. The upper row indicates patient code number. 
Table $4 \mathrm{LOH}$ at the TP53 locus in lung cancer specimens heterozygous for the codon 72 polymorphism

\begin{tabular}{lccc}
\hline & & \multicolumn{2}{c}{ Lost allele } \\
\cline { 3 - 4 } & p53 LOH & Arg & Pro \\
\hline Adenocarcinomas & $5 / 10$ & $1 / 5$ & $4 / 5$ \\
Squamous cell carcinomas & $7 / 12$ & $2 / 7$ & $5 / 7$ \\
Small cell carcinomas & $2 / 5$ & $0 / 2$ & $2 / 2$ \\
Total & $14 / 27$ & $3 / 14$ & $11 / 14$ \\
\hline
\end{tabular}

\section{HPV infection is a rare event in lung carcinogenesis}

In order to determine the frequency of HPV in advanced lung cancer, and to find a possible association with $p 53$ codon 72 polymorphism, matched biological specimens, from the upper (sputum) and lower (bronchial washing) respiratory system of each patient, were analysed for the presence of HPV, using the general primers GP5 and GP6. HPV DNA was detected in two cases $(3.7 \%)$, a squamous cell carcinoma and a large cell carcinoma. However, in the patient with squamous cell carcinoma, HPV was detected only in sputum and not in bronchial washing (Figure 2A). Multiplex PCR revealed that both patients harboured the high-risk HPV-18 type (Figure 2B). Although the Arg/Arg genotype of $p 53$ codon 72 polymorphism was observed in both HPV-positive cases, this finding was not statistically significant (Fisher's Exact test, $P=0.25$ ).

\section{DISCUSSION}

This population-based case-control study was conducted to examine the prevalence of $p 53$ codon 72 polymorphism in a Greek Caucasian population of advanced lung cancer patients and normal controls. The Arg/Arg homozygous genotype was statistically higher in patients than in controls $(50 \%$ vs $24.2 \%, P<0.002)$. This finding is in accordance with the original publication on HPVassociated cervical cancer (Storey et al, 1998), with previous studies by our group in cervical (Dokianakis and Spandidos, 2000), breast (Papadakis et al, 2000), skin (Dokianakis et al, 2000), laryngeal (Sourvinos et al, 2001) and bladder cancer (Soulitzis et al, 2002), as well as with another Greek study in cervical intra-epithelial neoplasia and cervical cancer (Agorastos et al, 2000).

Both study groups showed deviation from the Hardy-Weinberg equilibrium (Controls: $\chi_{\mathrm{HW}}^{2}=9.86, P<0.002$; Patients: $\chi_{\mathrm{HW}}^{2}=6.00$, $P<0.02$ ). Several studies exhibit this deviation in the control (Jin et al, 1995; Makni et al, 2000) or patients group (Kawajiri et al, 1993; Tandle et al, 2001). This cannot be attributed to methodological problems. The technique used to type this polymorphism (i.e. allele specific PCR), has a tendency to under-estimate heterozygotes (if an allele specific PCR product is not found, the specimen is characterised as homozygous for the other allele). On the contrary, the method that uses analysis with restriction enzymes, has a tendency to over-estimate heterozygotes (due to incomplete digestion of PCR products from the restriction enzyme). Therefore, regarding the cancer population, the Hardy-Weinberg equilibrium deviation could be attributed to selection bias due to the disease itself. As for the control group, it could be attributed to nonrandom selection, since enlisted subjects had specific characteristics (age, sex and smoking exposure) matching those of the cancer group. Nevertheless, from a statistical point of view, this HardyWeinberg equilibrium deviation does not affect our findings. Calculating the theoretical genotype frequencies for both controls and patients, the increase of Arg/Arg genotype in patients is statistically significant $\left(\chi^{2}=9.08, P<0.003, \mathrm{OR}=2.82, \mathrm{CI}=1.35-5.94\right)$. These values are only slightly lower than the ones calculated with
A

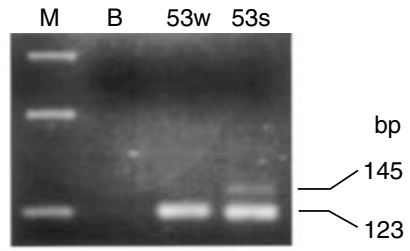

B

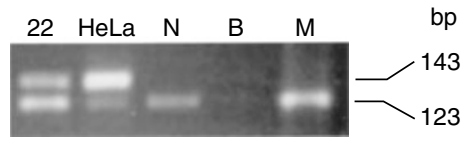

Figure 2 (A) Detection of HPV by PCR amplification using the general primers G5 and G6 (I 45 bp). 53w; bronchial washing. 53s; sputum. B; blank sample. M; 123 bp molecular weight marker. The band at 123 bp corresponds to the PCR product of $\beta 2-\mathrm{m}$ gene, which was used to establish the presence of amplifiable DNA. (B) Detection of HPV-I 8 by PCR amplification (I43 bp). 22; patient sample positive for HPV-I8. HeLa; positive control from HeLa cells. N; negative control. B; blank sample. M; I23 bp molecular weight marker. The band at 123 bp corresponds to the PCR product of $\beta 2-m$ gene, which was used to establish the presence of amplifiable DNA.

the observed genotypic frequencies $\left(\chi^{2}=10.43, \quad P<0.002\right.$, $\mathrm{OR}=3.13, \mathrm{CI}=1.46-6.73)$.

The frequency of Pro allele in the control group is $43.5 \%$. It has been proposed that geographical location and ethnicity play an important role in p53 allele frequencies (Beckman et al, 1994). Distribution of Pro allele in Caucasian populations varies from 24\% (Finland) (Beckman et al, 1994) to 53\% (India) (Tandle et $a l, 2001)$. Therefore, the Pro allele frequency of this study is not high, taking into account the geographical location of Greece and the genetic characteristics of our population. Furthermore, it is similar to that found by another Greek study (48\%) (Agorastos et al, 2000) and by a Turkish (a proximate population) study (39\%) (Toruner et al, 2001).

Several scientific groups have drawn opposite conclusions, associating p53Pro with lung carcinogenesis. This discrepancy could be attributed to various reasons. In some studies cancer population comprised patients eligible for surgical treatment (Stages I and II) excluding patients with more advanced tumours (Fan et al, 2000), whereas all of our cases were inoperable lung cancers (Stages IIIb and IV). Additionally, in studies involving advanced tumours, statistical analysis did not reveal any association of p53Pro with lung carcinogenesis (Wang et al, 1999). Moreover, variations in protocols among laboratories, or poor selection of the control group (Makni et al, 2000), could also explain the above mentioned discrepancies. However, it seems that the main reason is ethnic background. Populations across the earth exhibit significant differences in the frequency of $p 53$ codon 72 polymorphism, which can be attributed to natural selection through ecological adaptation to ultra-violet radiation (Beckman et al, 1994). Most studies that associate p53Pro with lung cancer have been conducted in Southeast Asia (China, Taiwan or Japan), where another p53 polymorphism (a 16 bp duplication in intron 3) is almost absent (frequency $<1.5 \%$ ). This $16 \mathrm{bp}$ duplication, combined with the Pro/Pro codon 72 genotype, offers protection against lung cancer. Therefore, the low frequency of the protective $16 \mathrm{bp}$ duplication in these populations would make it easier to demonstrate an association between p53Pro and cancer (Birgander et al, 1995).

Statistical analysis revealed that patients with Arg/Arg adenocarcinoma have lower pack-years of smoking history than those with 
Arg/Pro adenocarcinoma (30 vs 65, $P<0.001)$. This finding suggests that, as $p 53 \mathrm{Arg}$ confers susceptibility to lung carcinogenesis, lower dose of the carcinogen (tobacco) is required for tumour development. Larger studies, including phase I (CYPs) and phase II (GSTs and NATs) detoxification enzymes, are needed to verify this preliminary result.

Several functional assays demonstrate that the two polymorphic variants of $p 53$ have different biochemical and biological characteristics (Storey et al, 1998; Thomas et al, 1999; Marin et al, 2000). Codon 72 lies within a proline-rich domain of $p 53$ required for growth suppression (Walker and Levine, 1996) and apoptosis (Sakamuro et al, 1997). It comprises five PxxP SH3 (SRC-homology-3) binding motifs, one of which is lost when proline is replaced with arginine. This substitution could account for the difference that these two p53 variants exhibit in E6-mediated degradation, transcription activation and induction of apoptosis, and could explain the implication of codon 72 polymorphism in carcinogenesis.

Of the 14 heterozygous (Arg/Pro) specimens with LOH at the TP53 locus, $11(78 \%)$ retained the Arg allele, while only three (22\%) retained the Pro allele. Preferential deletion of p53Pro has also been described in HPV-associated oesophageal cancer (Kawaguchi et al, 2000), in squamous cell carcinoma of the vulva, regardless of HPV infection (Brooks et al, 2000) and in transitional cell carcinoma of the urinary tract (Furihata et al, 2002). The Arg isoform of $p 53$ codon 72 enhances certain $p 53$ mutants to form stable complexes with $p 73$, blocking the apoptotic ability of $p 73$ (Marin et al, 2000). Therefore, p53 mutants carrying the Arg allele can lead to decreased activation of $p 53$ target genes through inactivation of p73 (Tada et al, 2001). Thus, there is a strong bias to mutate and retain the Arg allele in tumours arising in Arg/Pro germline heterozygotes.

HPV was detected in two (3.7\%) lung cancer patients, a squamous cell carcinoma and a large cell carcinoma. The low

\section{REFERENCES}

Agorastos T, Lambropoulos AF, Constantinidis TC, Kotsis A, Bontis JN (2000) p53 codon 72 polymorphism and risk of intra-epithelial and invasive cervical neoplasia in Greek women. Eur J Cancer Prev 9: 113-118

Andersson S, Rylander E, Strand A, Sallstrom J, Wilander E (2001) The significance of $p 53$ codon 72 polymorphism for the development of cervical adenocarcinomas. Br J Cancer 85: 1153-1156

Beckman G, Birgander R, Sjalander A, Saha N, Holmberg PA, Kivela A, Beckman L (1994) Is $p 53$ polymorphism maintained by natural selection? Hum Hered 44: $266-270$

Birgander R, Sjalander A, Rannug A, Alexandrie AK, Sundberg MI, Seidegard J, Tornling G, Beckman G, Beckman L (1995) p53 polymorphisms and haplotypes in lung cancer. Carcinogenesis 16: 2233-2236

Bohlmeyer T, Le TN, Shroyer AL, Markham N, Shroyer KR (1998) Detection of human papillomavirus in squamous cell carcinomas of the lung by polymerase chain reaction. Am J Respir Cell Mol Biol 18: 265-269

Brooks LA, Tidy JA, Gusterson B, Hiller L, O'Nions J, Gasco M, Marin MC, Farrell PJ, Kaelin Jr WG, Crook T (2000) Preferential retention of codon 72 arginine $p 53$ in squamous cell carcinomas of the vulva occurs in cancers positive and negative for human papillomavirus. Cancer Res 60: 68756877

Cheng YW, Chiou HL, Sheu GT, Hsieh LL, Chen JT, Chen CY, Su JM, Lee H (2001) The association of human papillomavirus 16/18 infection with lung cancer among nonsmoking Taiwanese women. Cancer Res 61: 2799-2803

Clavel CE, Nawrocki B, Bosseaux B, Poitevin G, Putaud IC, Mangeonjean CC, Monteau M, Birembaut PL (2000) Detection of human papillomavirus DNA in bronchopulmonary carcinomas by hybrid capture II: a study of 185 tumors. Cancer 88: $1347-1352$

Dokianakis DN, Koumantaki E, Billiri K, Spandidos DA (2000) p53 codon 72 polymorphism as a risk factor in the development of HPV-associated nonmelanoma skin cancers in immunocompetent hosts. Int J Mol Med 5: $405-409$ frequency of HPV infection is consistent with previous studies performed in lung cancer (Kinoshita et al, 1995; Bohlmeyer et al, 1998; Clavel et al, 2000), suggesting that HPV is not an important factor in lung tumorigenesis. However, it is possible that the effect of HPV infection can only be estimated when other important carcinogenic factors, such as tobacco exposure, are not present (Cheng et al, 2001). Typing assay revealed that both cases harboured HPV-18. The high prevalence of this oncogenic HPV type in the Greek population could be attributed to ethnic variations (Dokianakis et al, 1999). In the case of squamous cell carcinoma, HPV DNA was detected only in sputum and not in bronchial washing. This could mean either that HPV infection was important solely as an early event in carcinogenesis and persistence of viral DNA was not necessary for cancer progression (Brooks et al, 2000), or that sputum was contaminated with cells from the upper respiratory tract or the oral cavity, infected with HPV. Both cases carried the Arg/Arg codon 72 genotype. Nevertheless, due to the low frequency of HPV infection, the association of p53Arg with lung carcinogenesis was not related to HPV.

In conclusion, our data associate p53Arg with advanced lung cancer and support the observation, that the Arg allele is preferentially retained in Arg/Pro germline heterozygotes. Nonetheless, additional population-based and functional studies are needed in order to elucidate the role of $p 53$ codon 72 polymorphism in lung cancer development.

\section{ACKNOWLEDGEMENTS}

The authors would like to thank Dr Despina Dokianakis and Dr George Sourvinos for providing the normal control population and Dr Triantafillos Liloglou for his useful remarks on the manuscript.

Dokianakis DN, Papaefthimiou M, Tsiveleka A, Spandidos DA (1999) High prevalence of HPV18 in correlation with ras gene mutations and clinicopathological parameters in cervical cancer studied from stained cytological smears. Oncol Rep 6: $1327-1331$

Dokianakis DN, Spandidos DA (2000) p53 codon 72 polymorphism as a risk factor in the development of HPV-associated cervical cancer. Mol Cell Biol Res Commun 3: $111-114$

Fan R, Wu MT, Miller D, Wain JC, Kelsey KT, Wiencke JK, Christiani DC (2000) The p53 codon 72 polymorphism and lung cancer risk. Cancer Epidemiol Biomarkers Prev 9: 1037-1042

Furihata M, Takeuchi T, Matsumoto M, Kurabayashi A, Ohtsuki Y, Terao N, Kuwahara M, Shuin T (2002) p53 mutation arising in Arg72 allele in the tumorigenesis and development of carcinoma of the urinary tract. Clin Cancer Res 8: $1192-1195$

Hamel N, Black MJ, Ghadirian P, Foulkes WD (2000) No association between $p 53$ codon 72 polymorphism and risk of squamous cell carcinoma of the head and neck. Br J Cancer 82: 757-759

Hirsch FR, Franklin WA, Gazdar AF, Bunn Jr PA (2001) Early detection of lung cancer: clinical perspectives of recent advances in biology and radiology. Clin Cancer Res 7: 5-22

Hollstein M, Sidransky D, Vogelstein B, Harris CC (1991) p53 mutations in human cancers. Science 253: $49-53$

Jemal A, Thomas A, Murray T, Thun M (2002) Cancer statistics, 2002. CA Cancer J Clin 52: 23-47

Jin X, Wu X, Roth JA, Amos CI, King TM, Branch C, Honn SE, Spitz MR (1995) Higher lung cancer risk for younger African-Americans with the Pro/Pro p53 genotype. Carcinogenesis 16: 2205-2208

Kawaguchi H, Ohno S, Araki K, Miyazaki M, Saeki H, Watanabe M, Tanaka S, Sugimachi K (2000) p53 polymorphism in human papillomavirus-associated esophageal cancer. Cancer Res 60: 2753-2755 
Kawajiri K, Nakachi K, Imai K, Watanabe J, Hayashi S (1993) Germ line polymorphisms of $p 53$ and CYP1A1 genes involved in human lung cancer. Carcinogenesis 14: $1085-1089$

Kinoshita I, Dosaka-Akita H, Shindoh M, Fujino M, Akie K, Kato M, Fujinaga K, Kawakami Y (1995) Human papillomavirus type 18 DNA and E6-E7 mRNA are detected in squamous cell carcinoma and adenocarcinoma of the lung. Br J Cancer 71: 344-349

Levine AJ (1997) p53, the cellular gatekeeper for growth and division. Cell 88: $323-33$

Makni H, Franco EL, Kaiano J, Villa LL, Labrecque S, Dudley R, Storey A, Matlashewski G (2000) p53 polymorphism in codon 72 and risk of human papillomavirus-induced cervical cancer: effect of inter-laboratory variation. Int J Cancer 87: 528-533

Marin MC, Jost CA, Brooks LA, Irwin MS, O'Nions J, Tidy JA, James N, McGregor JM, Harwood CA, Yulug IG, Vousden KH, Allday MJ, Gusterson B, Ikawa S, Hinds PW, Crook T, Kaelin Jr WG (2000) A common polymorphism acts as an intragenic modifier of mutant $p 53$ behaviour. Nat Genet 25: $47-54$

Matlashewski GJ, Tuck S, Pim D, Lamb P, Schneider J, Crawford LV (1987) Primary structure polymorphism at amino acid residue 72 of human $p 53$. Mol Cell Biol 7: $961-963$

Papadakis EN, Dokianakis DN, Spandidos DA (2000) p53 codon 72 polymorphism as a risk factor in the development of breast cancer. Mol Cell Biol Res Commun 3: 389-392

Pierce LM, Sivaraman L, Chang W, Lum A, Donlon T, Seifried A, Wilkens LR, Lau AF, Le Marchand L (2000) Relationships of TP53 codon 72 and HRAS1 polymorphisms with lung cancer risk in an ethnically diverse population. Cancer Epidemiol Biomarkers Prev 9: 1199-1204

Sakamuro D, Sabbatini P, White E, Prendergast GC (1997) The polyproline region of $p 53$ is required to activate apoptosis but not growth arrest. Oncogene 15: $887-898$

Scheffner M, Huibregtse JM, Vierstra RD, Howley PM (1993) The HPV-16 E6 and E6-AP complex functions as a ubiquitin-protein ligase in the ubiquitination of $p 53$. Cell 75: 495-505

Scheffner M, Werness BA, Huibregtse JM, Levine AJ, Howley PM (1990) The E6 oncoprotein encoded by human papillomavirus types 16 and 18 promotes the degradation of $p 53$. Cell 63: 1129-1136

Snijders PJ, van den Brule AJ, Schrijnemakers HF, Snow G, Meijer CJ, Walboomers JM (1990) The use of general primers in the polymerase chain reaction permits the detection of a broad spectrum of human papillomavirus genotypes. J Gen Virol 71: 173-181

Soulitzis N, Sourvinos G, Dokianakis DN, Spandidos DA (2002) p53 codon 72 polymorphism and its association with bladder cancer. Cancer Lett 179: $175-183$
Sourvinos G, Rizos E, Spandidos DA (2001) p53 codon 72 polymorphism is linked to the development and not the progression of benign and malignant laryngeal tumours. Oral Oncol 37: 572-578

Storey A, Thomas M, Kalita A, Harwood C, Gardiol D, Mantovani F, Breuer J, Leigh IM, Matlashewski G, Banks L (1998) Role of a p53 polymorphism in the development of human papillomavirus-associated cancer. Nature 393: $229-234$

Tada M, Furuuchi K, Kaneda M, Matsumoto J, Takahashi M, Hirai A, Mitsumoto Y, Iggo RD, Moriuchi T (2001) Inactivate the remaining $p 53$ allele or the alternate $p 73$ ? Preferential selection of the Arg72 polymorphism in cancers with recessive $p 53$ mutants but not transdominant mutants. Carcinogenesis 22: $515-517$

Takahashi T, Suzuki H, Hida T, Sekido Y, Ariyoshi Y, Ueda R (1991) The p53 gene is very frequently mutated in small-cell lung cancer with a distinct nucleotide substitution pattern. Oncogene 6: $1775-1778$

Tandle AT, Sanghvi V, Saranath D (2001) Determination of $p 53$ genotypes in oral cancer patients from India. $\mathrm{Br} J$ Cancer 84: 739-742

Tenti P, Vesentini N, Rondo Spaudo M, Zappatore R, Migliora P, Carnevali L, Ranzani GN (2000) p53 codon 72 polymorphism does not affect the risk of cervical cancer in patients from northern Italy. Cancer Epidemiol Biomarkers Prev 9: 435-438

Thomas M, Kalita A, Labrecque S, Pim D, Banks L, Matlashewski G (1999) Two polymorphic variants of wild-type $p 53$ differ biochemically and biologically. Mol Cell Biol 19: $1092-1100$

Toruner GA, Ucar A, Tez M, Cetinkaya M, Ozen H, Ozcelik T (2001) p53 codon 72 polymorphism in bladder cancer - no evidence of association with increased risk or invasiveness. Urol Res 29: 393-395

Viallet J, Minna JD (1990) Dominant oncogenes and tumor suppressor genes in the pathogenesis of lung cancer. Am J Respir Cell Mol Biol 2: 225-232

Walker KK, Levine AJ (1996) Identification of a novel $p 53$ functional domain that is necessary for efficient growth suppression. Proc Natl Acad Sci USA 93: $15335-15340$

Wang YC, Chen CY, Chen SK, Chang YY, Lin P (1999) p53 codon 72 polymorphism in Taiwanese lung cancer patients: association with lung cancer susceptibility and prognosis. Clin Cancer Res 5: 129-134

Zehbe I, Voglino G, Wilander E, Delius H, Marongiu A, Edler L, Klimek F, Andersson S, Tommasino M (2001) p53 codon 72 polymorphism and various human papillomavirus $16 \mathrm{E} 6$ genotypes are risk factors for cervical cancer development. Cancer Res 61: 608-611

zur Hausen H (1996) Papillomavirus infections - a major cause of human cancers. Biochim Biophys Acta 1288: F55-F78 